\title{
Audit Energi Listrik Pabrik
}

\author{
Deni Almanda ${ }^{1}$, Bayu Kusuma ${ }^{2}$ \\ 1),2) Jurusan Teknik Elektro, Fakultas Teknik, Universitas Muhammadiyah Jakarta \\ J1. Cempaka Putih Tengah 10510 \\ deni.almanda@ftumj.ac.id
}

\begin{abstract}
Abstrak
Audit energy adalah teknik yang digunakan untuk menghitung besarnya konsumsi energi pada suatu gedung dan mengetahui cara-cara untuk penghematan. Audit energy merupakan aktifitas berkala untuk mengetahui ada tidaknya penyimpangan dalam suatu kegiatan menelusuri dimana dan berapa energi yang digunakan, mengidentifikasikan ketidakseimbangan beban yang menimbulkan losses secara teknis serta mengevaluasi tingkat kelayakan. Adapun tujuan analisa ini adalah untuk mengevaluasi kualitas daya terhadap pengaruh faktor daya, unbalance load dan harmonisa akibat sistem mengkonsumsi beban secara tidak seimbang dan juga beban yang bersifat non-linear serta dampak yang ditimbulkannya terhadap sistem, dengan mengacu pada standar Institute of Electrical and Elecronic Engineers (IEEE) 519.1992.
\end{abstract}

Kata Kunci : audit, energi, itensitas, konsumsi, energi

\section{PENDAHULUAN}

Energi terlibat pada semua aspek kehidupan [1].Seiring dengan laju pertumbuhan pembangunan maka dituntut adanya sarana prasarana yang mendukung tercapainya tujuan pembangunan tersebut. Salah satu sarananya adalah dengan adanya penyediaan tenaga listrik. Saat ini tenaga listrik merupakan kebutuhan yang utama. Penyediaan tenaga listrik yang stabil dan berkesinambungan merupakan salah satu syarat mutlak yang harus dipenuhi dalam mencapai tujuan pembangunan tersebut. Saat ini elektronika berbahan semikonduktor organik menjadi perhatian karena fleksibel dan mudah di proses [2],[3],[4]. Secara umum, pemakai energi listrik di Indonesia dikelompokkan kedalam beberapa kelompok pelanggan, yaitu kelompok rumah tangga, industri, bisnis, sosial, kantor pemerintah, penerangan jalan umum serta multiguna. Mikrokontroler merupakan sebuah processor yang digunakan untuk kepentingan control [5]. Dalam era industri modern, sistem control proses industri biasanya merujuk pada otomatisasi sistem control yang digunakan [6]. Worldwide Interoperability for Microwave Acces atau Wimax adalah salah satu standar pada Broadband Wireless Access (BWA) yang diperkenalkan oleh Institute of Electrical and Electronic Engineering (IEEE) dikenal dengan sistem IEEE 802.16x [7]. Melihat perkembangan di bidang peralatan elektronik dewasa ini, perangkat multi media menjadi salah satu alat yang banyak digemari oleh mayoritas masyarakat dari seluruh kalangan [8]. Setiap kelompok dirinci kedalam sub kelompok masing-masing dan memiliki tarif/biaya pemakaian yang berbeda-beda. Namun dalam pemenuhan kebutuhan listrik tersebut, sering terjadi pembagian beban yang tidak seimbang. Pertimbangan utama analisa data adalah untuk mengetahui seberapa efisien penggunaan energi listrik, serta untuk mengetahui power losses unbalance dan harmonisa. Gangguan arus dan tegangan harmonik bisa mempengaruhi instalasi listrik [9].

\section{METODOLOGI}

Faktor daya $(\cos \mu)$ merupakan rasio perbandingan antara daya aktif (P) dengan daya semu (S), nilainya berkisar antara 0 hingga 1 . Beban resistif memiliki factor daya 1 dan beban induktif murni memiliki factor daya 0 [10]. Faktor daya yang tinggi memiliki kelebihan seperti pengurangan biaya dan rugi - rugi [11]. Perbaikan faktor daya juga membantu menghindari denda dan memberikan insentif kepada konsumen [12]. Hubungan matematika ketiga gaya tersebut dapat digambarkan dalam diagram segitiga daya. 
RESISTOR (elektRonika kEndali telekomunikaSI tenaga liSTrik kOmputeR) Vol. 1 No. 1 e-ISSN :

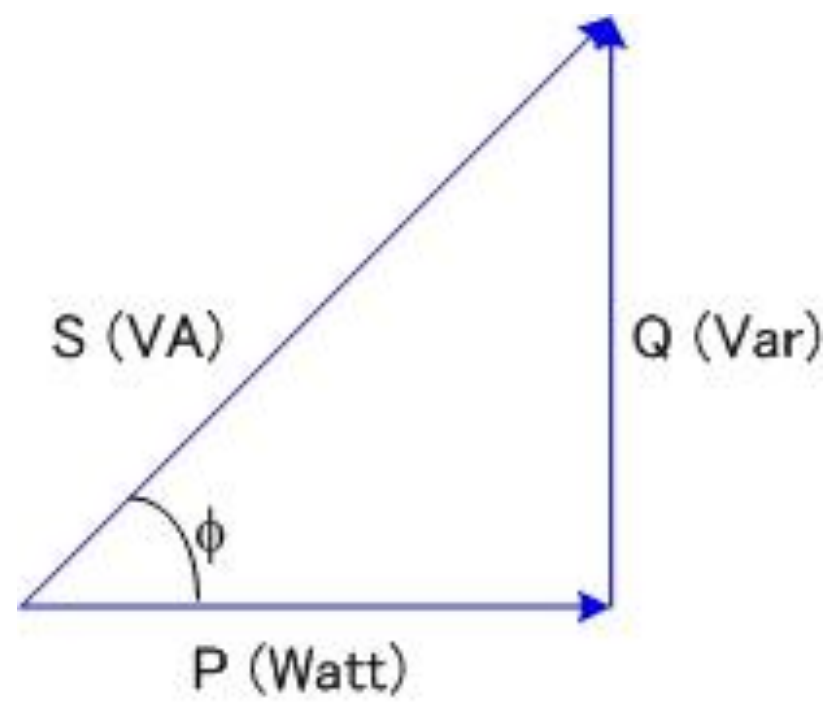

Gambar 1 Hubungan segitiga daya.

Salah satu cara untuk memperbaiki faktor daya adalah dengan memasang kompensasi kapasitif menggunakan kapasitor pada jaringan tersebut. Kapasitor adalah komponen listrik yang menghasilkan daya reaktif yang dibutuhkan oleh beban induktif pada jaringan dimana dia tersambung, sehihngga mengurangi daya yang diserap oleh beban induktif dari sumber tegangan pembangkit PLN. Sudut yang ditimbulkan kapasitor dan beban induktif mempunyai perbedaan $180^{\circ}$ atau saling berlawanan sehingga saling meniadakan. Pada segitiga daya seperti ditunjukan pada Gambar 1, apabila kapasitor dipasang maka daya reaktif yang disediakkan oleh sumber akan berkurang sebesar (yang merupakan daya reaktif berasal dari kapasitor). Karena daya aktif tidak berubah sedangkan daya reaktif berkurang, maka dari sudut pandang sumber, segitiga daya yang diperoleh; ditunjukan pada Gambar 2 garis oranye. Terlihat bahwa sudut $f$ mengecil akibat pemasangan kapasitor tersebut sehingga faktor daya jaringan akan naik. Nilai kapasitor yang optimal dibutuhkan untuk memperbaiki faktor daya [13].

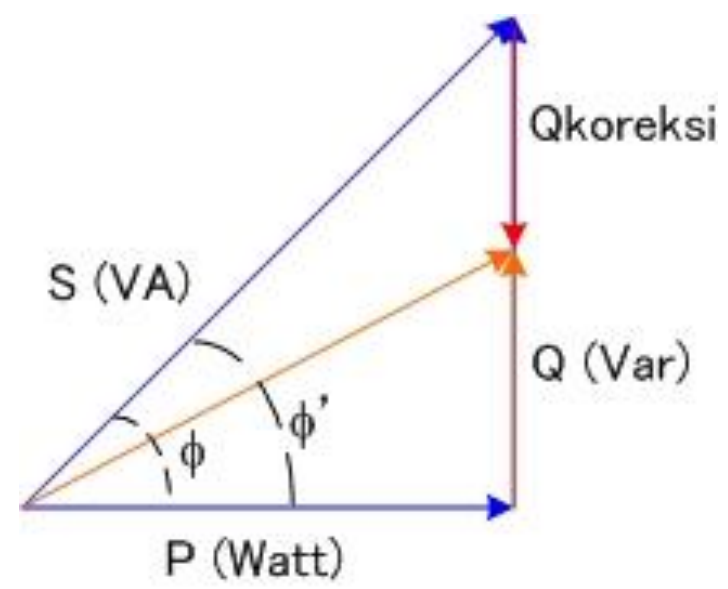

Gambar 2 Perbaikan faktor daya.

Harmonisa adalah tegangan ataupun arus sinusoida yang mempunyai frekuensi sebesar kelipatan dari frekuensi dasarnya. Frekuensi dasar adalah $50 \mathrm{~Hz}$, maka harmonisa kedua adalah gelombang dengan frekuensi $100 \mathrm{~Hz}$,harmonisa ketiga yaitu gelombang dengan frekuensi $150 \mathrm{~Hz}$ dan seterusnya. Gelombang - gelombang tersebut selanjutnya menumpang pada gelombang sinusoida frekuensi dasarnya atau sinusoida murni sehingga terbentuk gelombang sinusoida yang terdistorsi. Bentuk gelombang sinusoida murni dengan gelombang harmonisa dapat dilihat pada gambar dibawah ini.

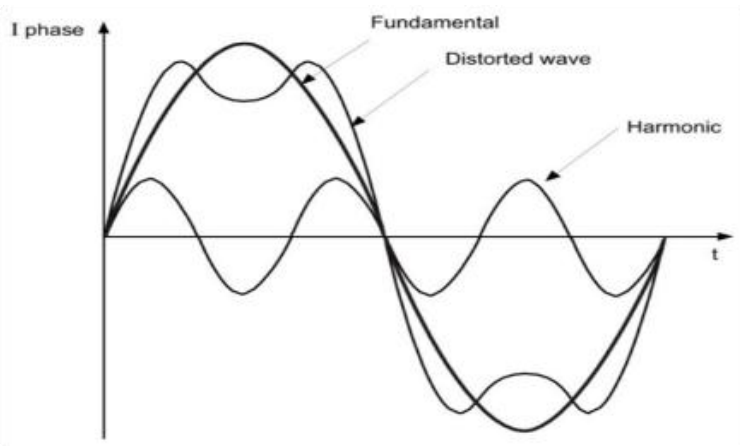

Gambar 3 Gelombang murni dan gelombang terdistorsi harmonisa.

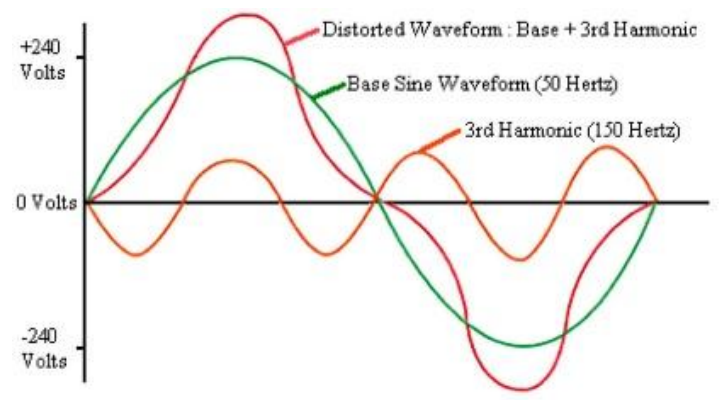


RESISTOR (elektRonika kEndali telekomunikaSI tenaga liSTrik kOmputeR) Vol. 1 No. 1 e-ISSN :

Gambar 4 Gelombang harmonisa ketiga dan kelima.

Berdasarkan sumber gelombangnya, kita ketahui ada harmonisa arus dan harmonisa tegangan. Harmonisa berdasarkan urutan ordenya dibedakan menjadi harmonisa urutan ganjil dan harmonisa urutan genap. Harmonisa urutan ganjil yaitu ke $3,5,7,9,11$ dan seterusnya. Urutan gelombang ke 1 adalah gelombang aslinya pada frekuensi $50 \mathrm{~Hz}$. Harmonisa genap yaitu harmonisa ke 2,4,6,8,10 dan seterusnya. Harmonisa berdasarkan urutan fasanya dibedakan menjadi 3 macam yaitu harmonisa urutan positif, harmonisa urutan nol dan harmonisa urutan negative. Harmonisa urutan positif (positive sequence) mempunyai fasa yang sama dengan gelombang murni frekuensi dasarnya $50 \mathrm{~Hz}$. Harmonisa urutan nol (zero sequence) tidak berpengaruh pada putaran medan, tapi menghasilkan panas pada komponen dan sistem.harmonisa urutan nol sering disebut juga dengan triplens harmoniks yaitu harmonisa ke 3,9,15 dan seterusnya. Harmonisa urutan negative (negative sequence) mempunyai fasa yang berlawanan dengan gelombang murni frekuensi dasarnya $50 \mathrm{~Hz}$.

Tabel 1 Polaritas orde harmonisa.

\begin{tabular}{|l|c|c|c|c|c|c|c|c|c|}
\hline Orde harmorisa & 1 & 2 & 3 & 4 & 5 & 6 & 7 & 8 & 9 \\
\hline Frekuensi $(\mathrm{Hz})$ & 50 & 100 & 150 & 200 & 250 & 300 & 350 & 400 & 450 \\
\hline Urutan Polaritas & + & - & 0 & + & - & 0 & + & - & 0 \\
\hline
\end{tabular}

Standar harmonisa yang diizinkan untuk arus dan tegangan berdasarkan standar IEEE 519-1992.

Tabel 2 Limit distorsi arus harmonisa.

\begin{tabular}{|c|c|c|c|c|c|c|}
\hline \multicolumn{7}{|c|}{$\begin{array}{l}\text { MAXIMUM HARMONIC CURRENT DISTORTION } \\
\text { In 听 of fundamental }\end{array}$} \\
\hline \multirow{2}{*}{$1 \mathrm{sc} / \mathrm{LL}$} & \multicolumn{6}{|c|}{ HARMONIC ORDER (ODD DISTORTION) } \\
\hline & $<11$ & $11<h<17$ & $17<h<23$ & $23<h<35$ & $35<\mathrm{h}$ & THD \\
\hline$<20$ & 4 & 2 & 1.5 & 0.6 & 0.3 & 5 \\
\hline $20-50$ & 7 & 3.5 & 2.5 & 1 & 0.5 & 8 \\
\hline $50-100$ & 10 & 4.5 & 4 & 1.5 & 0.7 & 12 \\
\hline $100-1000$ & 12 & 5.5 & 5 & 2 & 1 & 15 \\
\hline$>1000$ & 15 & 7 & 6 & 2.5 & 1.4 & 20 \\
\hline \multicolumn{7}{|c|}{ EVEN HARMONIC are limited to 25\% af the add harmanic limits abave } \\
\hline \multicolumn{7}{|c|}{$\begin{array}{l}\text { * All pawer generatian equipment in limited to these values af current } \\
\text { distartian, regarless of actual } \mathrm{s} c / \mathrm{lL}\end{array}$} \\
\hline \multicolumn{7}{|c|}{ Isc = maximum shart circuit current at PCC } \\
\hline \multicolumn{7}{|c|}{$\mathrm{IL}=$ maximum Iaad current (fundamental frequency) at PCC } \\
\hline
\end{tabular}

Tabel 3 Limit distorsi tegangan harmonisa.

\begin{tabular}{|l|c|c|c|}
\hline \multicolumn{4}{|c|}{$\begin{array}{c}\text { HARMONIC VOLTAGE DIS TORTION } \\
\text { In \% of fund amental }\end{array}$} \\
\hline & $\varsigma 69 \mathrm{kV}$ & $69-138 \mathrm{kV}$ & $>138 \mathrm{kV}$ \\
\hline Max for individual harmonic & 3 & 1.5 & 1 \\
\hline Total hammonic dis tortion (THD) & 5 & 2.5 & 1.5 \\
\hline
\end{tabular}

Filter harmonisa utamanya digunakan untuk menurunkan atau mereduksi amplitude frekuensi tertentu dan harmonisa tegangan atau harmonisa arus. Filter harmonisa dibedakan menjadi dua yaitu filter aktif dan filter pasif. Pada filter pasif terdapat komponen kapasitor, selain berfungsi sebagai filter juga diharapkan dapat memperbaiki faktor daya pada jala-jala listrik tersebut. Jenis filter pasif diantaranya yaitu :

1. Filter dengan penalaan tunggal (Single Tuned Shunt Filter)

2. Filter dengan penalaan ganda (Double Tuned Filter)

3. Damped Filter

Terdapat dua pilihan lokasi untuk penempatan filter yaitu filter dipasang pada bagian incoming trafo atau dipasang pada bagian outgoing trafo dekat dengan beban. Penempatan filter pasif sedapat mungkin dapat mereduksi gangguan harmonisa secara maksimal, diusahakan dekat dengan beban non linear. Gambar dibawah memperlihatkan dua pilihan lokasi penempatan filter harmonisa.

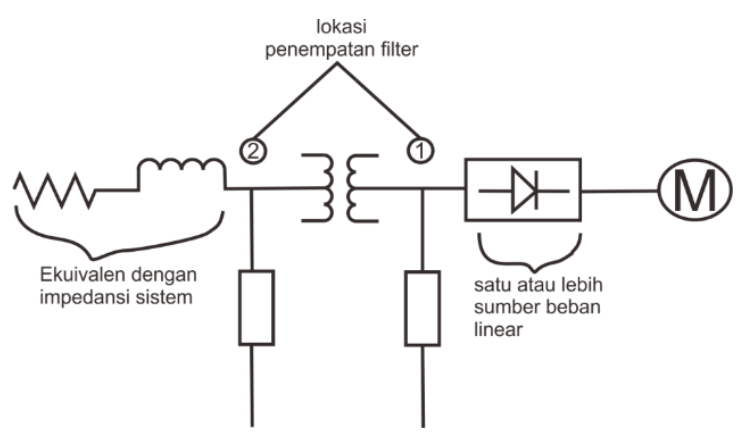

Gambar 5 Pilihan penempatan filter pasif.

Data pengambilan ini diperoleh dari hasil pengukuran yang dilakukan pada tanggal 1 Februari sampai 28 Februari 2015. Data Variabel yang diukur dan dianalisis pada penelitian ini adalah:

1. Frekuensi

2. Arus

3. Tegangan

4. Daya Semu

5. Daya Reaktif

6. Daya Aktif

7. Faktor Daya

8. Ketidakseimbangan Arus

9. Ketidakseimbangan Tegangan

10. Harmonisa Arus

11. Harmonisa Tegangan

Alat yang digunakan pada saat pengukuran kualitas daya listrik pada tiap Gedung Three Phase Power Quality Analyzer. Dalam pengukuran alat yang digunakan mampu mengukur besaran arus, tegangan, daya, faktor daya true, faktor daya 
RESISTOR (elektRonika kEndali telekomunikaSI tenaga liSTrik kOmputeR) Vol. 1 No. 1 e-ISSN :

displacement, dan lain-lain. Penelitian dilakukan dengan mengukur tiap panel listrik dengan durasi pengukuran 24 jam setiap panel. Pengukuran dilakukan pada hari kerja yaitu hari Senin sampai hari Sabtu. Setelah proses pengukuran selesai dilakukan analisis data kualitas daya listrik. Juga dilakukan perhitungan Power losses atau rugi-rugi daya yang diakibatkan oleh unbalance dan menghitung tariff dasar listrik dengan ketentuan yang sudah di tetapkan PLN.

Pengukuran dilakukan pada Main Distribution Panel (MDP) dan Sub Distribution Panel (SDP). Durasi pengukuran tiap panel selama 24 jam dengan interval waktu pengambilan data setiap 2 menit. Langkah-langkah yang dilakukan antara lain:

1. Menghubungkan MN93 pada masing-masing fasa $\mathrm{R}, \mathrm{S}, \mathrm{T}$ panel, dengan pola warna yang sesuai.

2. Menghubungkan jumper tegangan pada fasa $R$, $\mathrm{S}$, T serta grounding pada panel sesuai warna masing-masing, kemudian dikoneksikan pada pada alat ukur Three Phase Power Quality Analyzer.

3. Konfigurasi recording atau perekaman meliputi nama, durasi pengukuran dan durasi interval pengambilan data.

4. Start recording.

5. Setelah data selesai direkam langkah selanjutnya adalah transfer data hasil rekaman dari alat ukur Three Phase Power Quality Analyzer ke komputer.

\section{ANALISA DATA HASIL PENGUKURAN}

Daya terpasang pada gedung masuk ke dalam golongan pengguna listrik tarif industri dengan daya sebesar 345 KVA. Data hasil pengukuran panel MDP pada tanggal 16 Februari 2015 sampai dengan 17 Februari 2015. Berdasarkan hasil pengukuran yang telah dilakukan di panel MDP, maka dengan menggunakan nilai rata-rata parameter dapat ditabulasikan sebagai berikut :

Tabel 4.12 Nilai rata-rata data hasil pengukuran panel mdp.

\begin{tabular}{|c|c|c|c|c|c|}
\hline No & Parameter & Fasg $R$ & Fags S & Fass T & Netral \\
\hline 1 & Frekuensi $(\mathrm{Hz})$ & \multicolumn{3}{|c|}{49.979} & \\
\hline 2 & Tegangan (V́lt) & 226.395 & 225.006 & 225.490 & \\
\hline 3 & HarmanisaTegangan ("6) & 3.164 & 3.814 & 3.814 & \\
\hline 4 & Arus (A) & 41.567 & 74.010 & 88.827 & 38.495 \\
\hline 5 & HarmanisaArus ("6) & 8.176 & 9.851 & 9.350 & \\
\hline 6 & DayaAkt if (W) & 9236.299 & 16405.52 & 18816.78 & \\
\hline 7 & DayaReaktif (var) & 620.553 & 2779.721 & 6514.130 & \\
\hline 8 & DayaSemu (VA) & 9403.759 & 16653.9 & 20024.39 & \\
\hline 9 & Faktar Daya & 0.974 & 0.983 & 0.930 & \\
\hline 10 & VUnbalance, IEEE (西) & \multicolumn{3}{|c|}{0.380} & \\
\hline 11 & A. Unbalance, IEEE (ס) & \multicolumn{3}{|c|}{40.958} & \\
\hline
\end{tabular}

Berdasarkan data hasil pengukuran dapat dilihat bahwa THD tegangan pada fasa R, S dan T masih dalam kondisi bagus yaitu dibawah 5\%. THD arus pada panel MDP masih dalam keadaan baik karena masih berada dibawah standar IEEE No. 5191992 yaitu sebesar 15\%. Data hasil pengukuran tegangan listrik rata-rata masih berada dalam rentang standar yang diizinkan yaitu batas naik turun tegangan adalah 198-231V. Sedangkan pada hasil pengukuran arus listrik menunjukkan bahwa beban berada pada keadaan tidak seimbang. Hal ini ditunjukkan dengan nilai arus perfasa yang memiliki perbedaan cukup besar dan arus netral yang besarnya mendekati fasa R. Faktor daya terukur pada fasa R, S, T bernilai $0.97,0.98,0.93$ berada diatas standar PLN sebesar 0.85 Voltage Unbalance (ketidakseimbangan beban) masih aman karena belum melewati batas standar IEEE yaitu sebesar $2 \%$. Berdasarkan data hasil pengukuran dapat disimpulkan bahwa panel MDP mempunyai masalah pada ketidakseimbangan beban. Data hasil pengukuran panel pada 22 Februari 2015 sampai dengan 23 Februari 2015. Berdasarkan hasil pengukuran yang telah dilakukan di panel gedung Perakitan Televisi, maka dengan menggunakan nilai rata-rata parameter dapat ditabulasikan sebagai berikut :

Tabel 4 Nilai rata-rata hasil pengukuran panel gedung perakitan televisi.

\begin{tabular}{|c|c|c|c|c|c|}
\hline No & Parameter & Fass $R$ & Fass 5 & Fass $T$ & Netral \\
\hline 1 & Frekuensi ( $\mathrm{Hz})$ & & & 49.993 & \\
\hline 2 & Tegangan (V'alt) & 225.317 & 223.963 & 225.014 & \\
\hline 3 & $\begin{array}{l}\text { Harmanisa } \\
\text { Tegangan (6) }\end{array}$ & 3.320 & 4.004 & 3.7 & \\
\hline 4 & Arus (A) & 148.989 & 85.889 & 124.872 & 73.457 \\
\hline 5 & HarmunisaA.rus ("6) & 7.366 & 7.464 & 9.951 & \\
\hline 6 & Daya Akt if (W) & 27781.21 & 18440.31 & 24111.27 & \\
\hline 7 & Daya Reakt if (Yar) & 18156.558 & 4656.845 & 13999.6 & \\
\hline 8 & Daya Semu ( $(A)$ ) & 33583.949 & 19242.759 & 28099.77 & \\
\hline 9 & Faktar Daya & 0.830 & 0.955 & 0.854 & \\
\hline 10 & $\begin{array}{l}\text { VUnbalance, } \\
\text { IEEE (क) }\end{array}$ & & & 0.367 & \\
\hline 11 & $\begin{array}{l}\text { A. Unbalance, } \\
\text { IEEE (ס) }\end{array}$ & & & .507 & \\
\hline
\end{tabular}

Berdasarkan hasil pengukuran panel Gedung Perakitan Televisi dapat dilihat bahwa THD arus masih dalam keadaan baik karena masih berada dibawah standar IEEE antara lain sebesar 7.36\% untuk fasa R, 7.46\% untuk fasa S, dan 9.95\%. Juga untuk THD tegangan masih dalam kondisi baik karena masih berada dibawah standar IEEE. Hasil pengukuran tegangan listrik rata-rata masih berada dalam rentang standar yang diizinkan yaitu batas naik turun tegangan adalah $-10 \%$ dan $5 \%$ sebesar 198-231V. Sedangkan pada hasil pengukuran arus listrik menunjukan hasil yang tidak seimbang antar 
RESISTOR (elektRonika kEndali telekomunikaSI tenaga liSTrik kOmputeR) Vol. 1 No. 1 e-ISSN :

fasanya. Bahkan nilai arus netralnya mendekati nilai fasa $S$ yaitu sebesar $73.45 \mathrm{~A}$ sedangkan pada fasa $\mathrm{S}$ bernilai sebesar 85.88 A. Nilai pada fasa $R$ dan $T$ terlampau jauh yaitu sebesar 148.98 A dan 124.87 A. Faktor daya terukur pada fasa R, S, T bernilai $0.83,0.95,0.85$ berada diatas standar PLN sebesar 0.85 Voltage Unbalance (ketidakseimbangan beban) masih aman karena belum melewati batas standar IEEE yaitu sebesar 2\%. Berdasarkan hasil pengukuran panel Gedung Perakitan Televisi mempunyai masalah ketidakseimbangan beban. Data hasil pengukuran panel pada tanggal 20 Februari 2015 sampai dengan 21 Februari 2015. Berdasarkan hasil pengukuran yang telah dilakukan di panel Gedung Perakitan Handphone maka dengan menggunakan nilai rata-rata parameter dapat ditabulasikan sebagai berikut :

Tabel 5 Nilai rata-rata hasil pengukuran panel gedung perakitan handphone.

\begin{tabular}{|c|c|c|c|c|c|}
\hline No & Parameter & Fags $\mathrm{R}$ & Fass S & Fass $T$ & Netral \\
\hline 1 & Frekuensi ('Hz) & \multicolumn{3}{|c|}{49.940} & \\
\hline 2 & Tegangan (V́alt) & 226.526 & 224.906 & 225.006 & \\
\hline 3 & 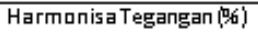 & 3.521 & 4.211 & 3.943 & \\
\hline 4 & Arus (A) & 2.052 & 4.844 & 2.243 & 4.926 \\
\hline 5 & HarmanisaArus (贮) & 42.896 & 13.361 & 27.090 & \\
\hline 6 & Daya A.kt if (W) & 390.380 & 1026.142 & 339.500 & \\
\hline 7 & Daya Reaktif (Yar) & 47.984 & 375.597 & -370.769 & \\
\hline 8 & Daya Semu (WA) & 475.265 & 1100.730 & 510.014 & \\
\hline 9 & Faktar Daya & 0.700 & 0.934 & 0.692 & \\
\hline 10 & VUnbalance, IEEE (\%) & \multicolumn{3}{|c|}{0.487} & \\
\hline 11 & \& Unbalance, IEEE (吅) & \multicolumn{3}{|c|}{64.296} & \\
\hline
\end{tabular}

Berdasarkan hasil pengukuran pada panel Gedung Perakitan Handphone dapat dilihat bahwa THD arus dalam keadaan tidak baik karena melebihi standar IEEE yang besarnya antara lain pada fasa $\mathrm{R}$ $42.8 \%$, pada fasa $\mathrm{S}$ sebesar $13.3 \%$, dan pada fasa $\mathrm{T}$ sebesar $27.0 \%$. Dari data tersebut dapat dilihat bahwa besarnya THD arus pada fasa $\mathrm{R}$ dan $\mathrm{T}$ melebihi batas standar yaitu sebesar $15 \%$, sedangkan pada fasa $\mathrm{S}$ masih dibawah $15 \%$. Kemudian untuk THD tegangan masih dalam kondisi baik karena masih berada dibawah standar IEEE yaitu sebesar $5 \%$, besarnya THD tegangan tersebut antara lain pada fasa R $3.5 \%$, pada fasa $\mathrm{S} 4.2 \%$, dan pada fasa $\mathrm{T}$ $3.9 \%$. Hasil pengukuran tegangan listrik rata-rata masih berada dalam rentang yang diizinkan yaitu batas naik turun adalah $-10 \%$ dan $+5 \%$ sebesar 193 $231 \mathrm{~V}$. Pada hasil pengukuran arus rata-rata terjadi ketidaksimbangan beban, arus pada fasa netral besarnya hampir sama dengan fasa $\mathrm{S}$ yaitu sebesar 4.9A. Hal ini dapat diartikan bahwa pada panel Gedung Perakitan Handphone terjadi ketidaksembangan beban. Faktor daya pada panel arafah terukur pada fasa $\mathrm{R}$ sebesar 0.7 , fasa $\mathrm{S}$ sebesar 0.93, dan fasa $\mathrm{T}$ sebesar 0.69 masih berada

diatas standar PLN sebesar 0.85 Voltage Unbalance (ketidakseimbangan beban) masih aman karena belum melewati batas standar IEEE yaitu sebesar $2 \%$. Berdasarkan hasil pengukuran dapat disimpulkan bahwa di Gedung Perakitan Handphone mengalami masalah pada harmonisa arus dan ketidakseimbangan beban. Hal ini berarti kualitas daya pada panel Gedung Perakitan Handphone buruk.

Data hasil pengukuran panel Gedung Logistik pada tanggal 22 Februari 2015 sampai dengan 23 Februari 2015. Berdasarkan hasil pengukuran yang telah dilakukan di Panel Gedung Logistik, maka dengan menggunakan nilai rata-rata parameterparameter di atas dapat ditabulasikan sebagai berikut

Tabel 6 Nilai rata-rata hasil pengukuran panel gedung logistik.

\begin{tabular}{|c|c|c|c|c|c|}
\hline No & Parameter & Fass $R$ & Fass S & Fass T & Netral \\
\hline 1 & Frekuensi ('Hz) & \multicolumn{3}{|c|}{50.019} & \\
\hline 2 & Tegangan (valt) & 226.760 & 224.537 & 224.987 & \\
\hline 3 & HarmanisaTegangan ("6) & 3.398 & 4.022 & 3.824 & \\
\hline 4 & Arus (A) & 1.998 & 3.106 & 1.927 & 2.463 \\
\hline 5 & HarmanisaArus ("6) & 22.391 & 13.184 & 27.345 & \\
\hline 6 & Daya A.kt if (W) & 282.098 & 693.805 & 289.843 & \\
\hline 7 & Daya Reakt if (Yar) & -335.039 & -13.065 & -314.457 & \\
\hline 8 & Daya Semu (WA) & 455.896 & 708.322 & 435.133 & \\
\hline 9 & Faktar Daya & 0.468 & 0.979 & 0.660 & \\
\hline 10 & VUnbalance, IEEE (\%) & \multicolumn{3}{|c|}{0.598} & \\
\hline 11 & A Unbalance, IEEE (响) & \multicolumn{3}{|c|}{43.336} & \\
\hline
\end{tabular}

Berdasarkan hasil pengukuran pada Panel Gedung Logistik dapat dilihat bahwa THD arus dalam keadaan tidak baik karena melebihi standar IEEE yang besarnya antara lain pada fasa R $22.3 \%$, pada fasa $\mathrm{S}$ sebesar $13.1 \%$, dan pada fasa $\mathrm{T}$ sebesar 27.3\%. Dari data tersebut dapat dilihat bahwa besarnya THD arus pada fasa $\mathrm{R}$ dan $\mathrm{T}$ melebihi batas standar yaitu sebesar $15 \%$, sedangkan pada fasa S masih dibawah $15 \%$. Kemudian untuk THD tegangan masih dalam kondisi baik karena masih berada dibawah standar IEEE yaitu sebesar 5\%, besarnya THD tegangan tersebut antara lain pada fasa $\mathrm{R} 3.3 \%$, pada fasa $\mathrm{S} 4.0 \%$, dan pada fasa $\mathrm{T}$ $3.8 \%$.Hasil pengukuran tegangan listrik rata-rata masih berada dalam rentang yang diizinkan yaitu batas naik turun adalah $-10 \%$ dan $+5 \%$ sebesar 193 231V. Pada hasil pengukuran arus rata-rata terjadi ketidakseimbangan beban, yaitu nilai arus pada fasa netral sebesar 2.4A. Hal ini dapat diartikan bahwa pada Panel Gedung Logistik terjadi ketidakseimbangan beban. Faktor daya pada Panel Gedung Logistik terukur pada fasa R sebesar 0.4, fasa $\mathrm{S}$ sebesar 0.97 , dan fasa $\mathrm{T}$ sebesar 0.66 masih berada diatas standar PLN sebesar 0.85 Voltage 
RESISTOR (elektRonika kEndali telekomunikaSI tenaga liSTrik kOmputeR) Vol. 1 No. 1 e-ISSN :

Unbalance (ketidakseimbangan beban) masih aman karena belum melewati batas standar IEEE yaitu sebesar 2\%. Berdasarkan hasil pengukuran dapat disimpulkan bahwa Panel Gedung Logistik mengalami masalah pada harmonisa arus dan ketidakseimbangan beban. Hal ini berarti kualitas daya pada Panel Gedung Logistik buruk.

Hasil pengukuran Panel Perkantoran dan Workshop ada tanggal 24 Februari 2015 sampai dengan 25 Februari 2015. Berdasarkan hasil pengukuran yang telah dilakukan di Panel Perkantoran dan Workshop, maka dengan menggunakan nilai rata-rata parameter dapat ditabulasikan sebagai berikut :

Tabel 7 Nilai nilai rata-rata hasil pengukuran panel perkantoran dan workshop.

\begin{tabular}{|c|c|c|c|c|c|}
\hline $\mathrm{No}$ & Parameter & Fasg $R$ & Fasg 5 & Fass T & Netral \\
\hline 1 & Frekuensi (Hz) & \multicolumn{3}{|c|}{49.989} & \\
\hline 2 & Tegangan (V́alt') & 225.427 & 224.331 & 223.487 & \\
\hline 3 & $\begin{array}{l}\text { Harmanisa } \\
\text { Tegangan (66) }\end{array}$ & 3.341 & 3.874 & 3.709 & \\
\hline 4 & Arus (A) & 37.087 & 34.924 & 49.787 & 21.602 \\
\hline 5 & HarmonisaA.rus ("6) & 12.070 & 11.576 & 7.378 & \\
\hline 6 & Daya Akt if $(W)$ & 7982.738 & 7697.302 & 11038.29 & \\
\hline 7 & Daya Reakt if (Yrar) & 2277.006 & 1403.492 & -468.244 & \\
\hline 8 & Daya Semu (VA) & 8364.601 & 7838.467 & 11116.15 & \\
\hline 9 & Faktar Daya & 0.945 & 0.978 & 0.991 & \\
\hline 10 & VUnbalance, IEEE (\%) & & 0.559 & & \\
\hline 11 & \& Unbalance, IEEE (\%) & & 28.946 & & \\
\hline
\end{tabular}

Berdasarkan hasil pengukuran pada Panel Perkantoran dan Workshop dapat dilihat bahwa THD arus dalam baik karena masih berada dibawah standar IEEE yang besarnya antara lain pada fasa $\mathrm{R}$ $12.0 \%$, pada fasa $\mathrm{S}$ sebesar $11.5 \%$, dan pada fasa $\mathrm{T}$ sebesar $7.3 \%$. Kemudian untuk THD tegangan masih dalam kondisi baik karena masih berada dibawah standar IEEE yaitu sebesar 5\%, besarnya THD tegangan tersebut antara lain pada fasa $\mathrm{R}$ $3.3 \%$, pada fasa S $3.8 \%$, dan pada fasa T $3.7 \%$. Hasil pengukuran tegangan listrik rata-rata masih berada dalam rentang yang diizinkan yaitu batas naik turun adalah $-10 \%$ dan $+5 \%$ sebesar 193-231V. Pada hasil pengukuran arus rata-rata dapat dikatakan cukup seimbang karena rentang selisih arus yang tidak terlalu besar dan nilai arus netral juga berada dibawah ketiga fase. Faktor daya pada Panel Perkantoran dan Workshop terukur pada fasa $\mathrm{R}$ sebesar 0.94, fasa S sebesar 0.97, dan fasa T sebesar 0.99 masih berada diatas standar PLN sebesar 0.85 Voltage Unbalance (ketidakseimbangan beban) masih aman karena belum melewati batas standar IEEE yaitu sebesar 2\%. Berdasarkan hasil pengukuran dapat disimpulkan bahwa kualitas daya listrik Panel Perkantoran dan Workshop cukup baik. Panel ini mensuplai beberapa ruangan antara lain Ruang CCTV, Fasilitas Karyawan dan Kantin.
Pengukuran panel ini dilakukan pada tanggal 25 Februari 2015 sampai dengan 26 Februari 2015. Berdasarkan data hasil pengukuran yang telah dilakukan di panel ini, maka dengan menggunakan nilai rata-rata parameter dapat ditabulasikan sebagai berikut :

Tabel 8 Nilai nilai rata-rata hasil pengukuran panel ruang cctv, fasilitas karyawan dan kantin.

\begin{tabular}{|c|c|c|c|c|c|}
\hline No & Parameter & Fasg $R$ & Fag S & Fasg T & Netral \\
\hline 1 & Frekuensi ( $\mathrm{Hz})$ & \multicolumn{3}{|c|}{49.962} & \\
\hline 2 & Tegangan (v'alt) & 225.970 & 224.660 & 224.112 & \\
\hline 3 & $\begin{array}{l}\text { Harmanisa } \\
\text { Tegangan (6) }\end{array}$ & 3.249 & 3.854 & 3.630 & \\
\hline 4 & A.rus (A) & 43.973 & 40.237 & 38.955 & 20.639 \\
\hline 5 & Harmanisa Arus ("6) & 6.526 & 6.912 & 6.100 & \\
\hline 6 & Daya Akt if (W) & 8405.604 & 8776.711 & 8600.479 & \\
\hline 7 & Daya Reakt if (Yvar) & 5298.465 & 1969.202 & 826.881 & \\
\hline 8 & Daya Semu(YA) & 9948.257 & 9044.587 & 8742.79 & \\
\hline 9 & Faktar Daya & 0.843 & 0.966 & 0.983 & \\
\hline 10 & $\begin{array}{l}\text { VUnbalance, } \\
\text { IEEE (क) }\end{array}$ & \multicolumn{3}{|c|}{0.491} & \\
\hline 11 & $\begin{array}{l}\text { A. Unbalance, } \\
\text { IEEE ('6) }\end{array}$ & \multicolumn{3}{|c|}{14.070} & \\
\hline
\end{tabular}

Berdasarkan hasil pengukuran pada panel Ruang CCTV, Fasilitas Karyawan dan Kantin dapat dilihat bahwa THD arus dalam baik karena masih berada dibawah standar IEEE yang besarnya antara lain pada fasa $\mathrm{R} 6.5 \%$, pada fasa $\mathrm{S}$ sebesar $6.9 \%$, dan pada fasa $\mathrm{T}$ sebesar $6.1 \%$. Kemudian untuk THD tegangan masih dalam kondisi baik karena masih berada dibawah standar IEEE yaitu sebesar $5 \%$, besarnya THD tegangan tersebut antara lain pada fasa R $3.2 \%$, pada fasa S $3.8 \%$, dan pada fasa $\mathrm{T}$ $3.6 \%$. Hasil pengukuran tegangan listrik rata-rata masih berada dalam rentang yang diizinkan yaitu batas naik turun adalah $-10 \%$ dan $+5 \%$ sebesar 193 231V. Pada hasil pengukuran arus rata-rata dapat dikatakan cukup seimbang karena rentang selisih arus yang tidak terlalu besar dan nilai arus netral juga berada dibawah ketiga fase.Faktor daya pada panel Ruang CCTV, Fasilitas Karyawan dan Kantin terukur pada fasa $\mathrm{R}$ sebesar 0.84 , fasa $\mathrm{S}$ sebesar 0.96, dan fasa $\mathrm{T}$ sebesar 0.98 masih berada diatas standar PLN sebesar 0.85 Voltage Unbalance (ketidakseimbangan beban) masih aman karena belum melewati batas standar IEEE yaitu sebesar $2 \%$. Berdasarkan hasil pengukuran dapat disimpulkan bahwa kualitas daya listrik pada panel Ruang CCTV, Fasilitas Karyawan dan Kantin cukup baik. Besar hambatan penghantar kabel fasa dan netral sama yaitu sebesar $0.124 \Omega$ per-kilometer. Besar hambatan penghantar ini sesuai dengan spesifikasi kabel yang digunakan dalam instalasi yaitu kabel NYY supreme dengan luasan kabel perfasa sebesar $150 \mathrm{~mm}^{2}$. Diasumsikan bahwa jarak tiap masing-masing gedung ke trafo sama yaitu sejauh $1 \mathrm{~km}$. Dengan demikian besar hambatan 
RESISTOR (elektRonika kEndali telekomunikaSI tenaga liSTrik kOmputeR) Vol. 1 No. 1 e-ISSN :

penghantar pada tiap gedung sama yaitu sebesar $0.124 \Omega$.

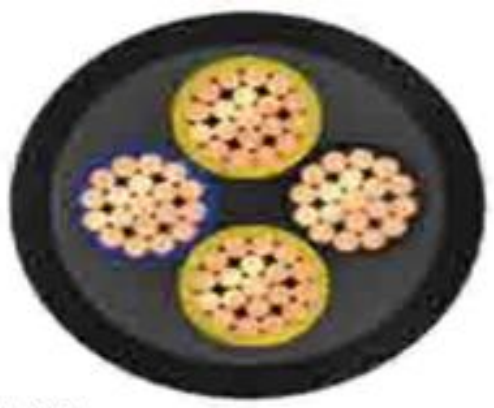

ELECTRICAL DATA

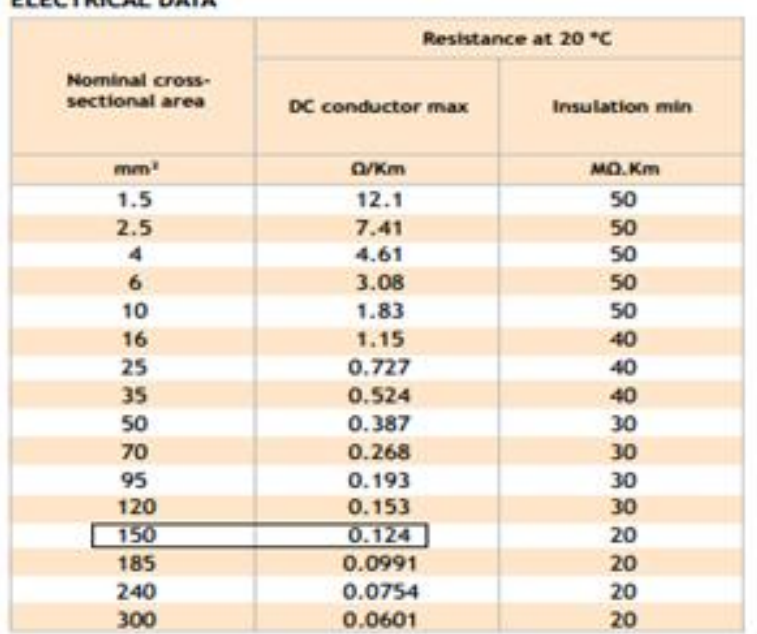

Gambar 6 Spesfikasi kabel NYY supreme $150 \mathrm{~mm}^{2}$.

Tabel 9 Nilai arus harmonik tiap panel.

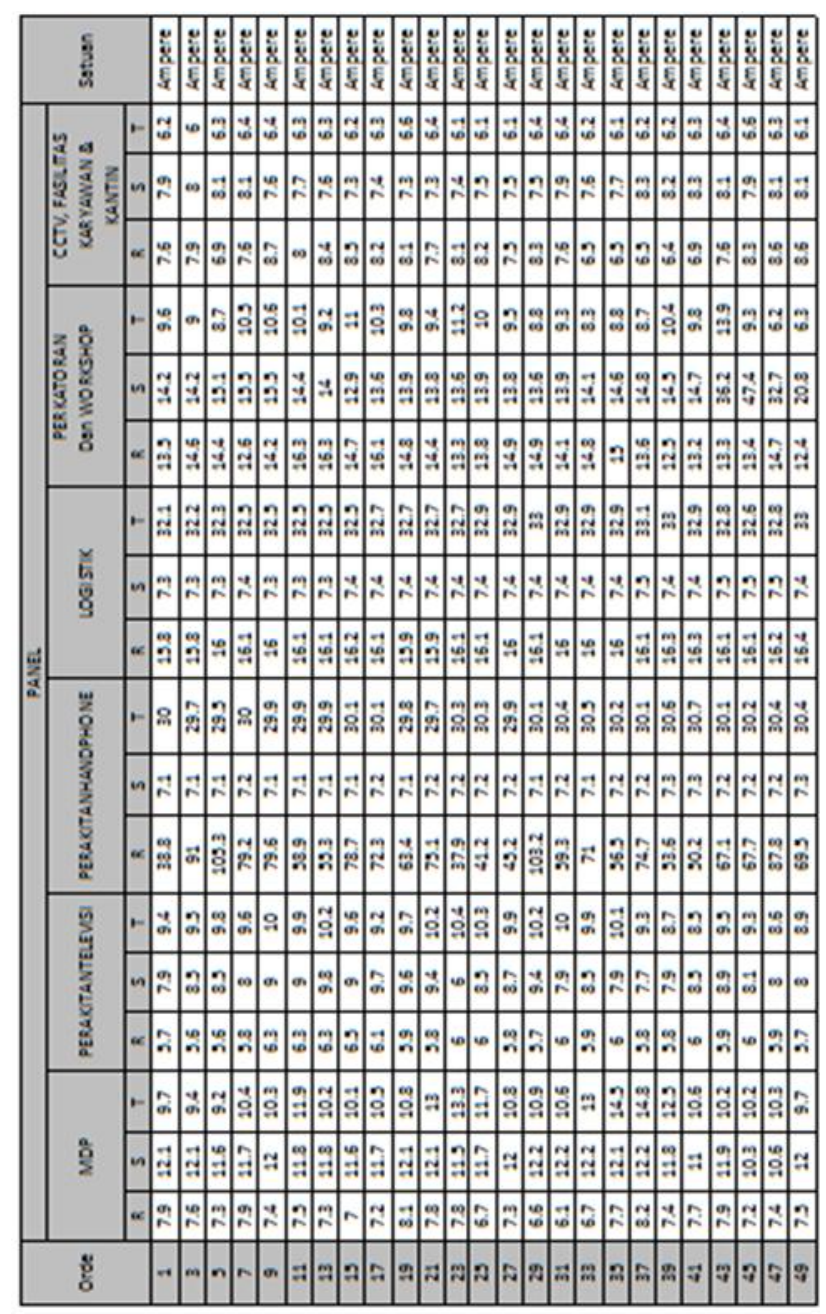

Berikut data hasil perhitungan Power losses pada fasa $\mathrm{R}, \mathrm{S}$, dan $\mathrm{T}$ semua panel.

Tabel 10 Besar power losses fasa R, S dan T.

\begin{tabular}{|l|c|c|c|c|}
\hline & Fas a R & Fas a S & Fas a T & Satuan \\
\hline Panel MDP & 22.968 & 36.493 & 34.546 & Watt \\
\hline $\begin{array}{l}\text { Panel Gedung } \\
\text { Perakitan Televis i }\end{array}$ & 18.401 & 26.585 & 29.846 & Watt \\
\hline $\begin{array}{l}\text { Panel Gedung } \\
\text { Perakitan Handphane }\end{array}$ & 208.63 & 22.233 & 93.347 & Watt \\
\hline Panel Gedung Lagis tik & 49.832 & 22.915 & 101.382 & Watt \\
\hline $\begin{array}{l}\text { Panel Gedung } \\
\text { Perkantaran dan Warks hap }\end{array}$ & 44.119 & 54.026 & 29.598 & Watt \\
\hline $\begin{array}{l}\text { Panel Ruang CcT, } \\
\text { Fasilitæ Karyawan dan Kantin }\end{array}$ & 23.956 & 24.105 & 19.455 & Watt \\
\hline
\end{tabular}

Tabel 11 Nilai arus netral harmonik tiap panel. 
RESISTOR (elektRonika kEndali telekomunikaSI tenaga liSTrik kOmputeR) Vol. 1 No. 1 e-ISSN :

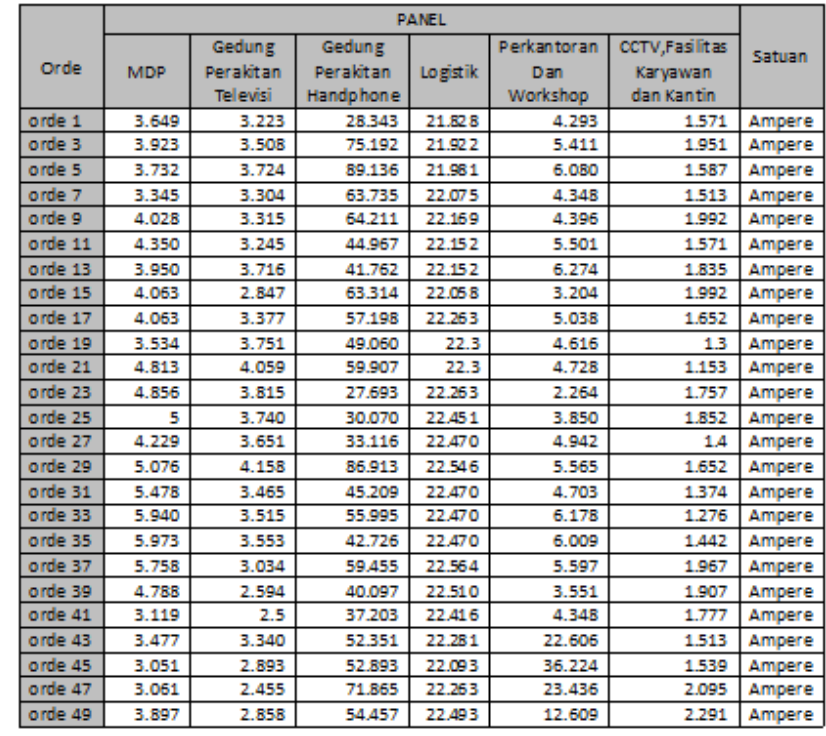

Berikut besar power losses akibat arus netral harmonik pada masing-masing panel :

Tabel 12 Besar power losses pada kawat netral.

\begin{tabular}{|l|r|c|}
\hline & \multicolumn{1}{|c|}{ Netral } & Satuan \\
\hline Panel MDP & 13.284 & Watt \\
\hline Panel Gedurg Perakitan Televisi & 10.372 & Watt \\
\hline Panel Gedurg Perakitan Handphane & 164.533 & Watt \\
\hline Lagis tik & 69.064 & Watt \\
\hline Perkantaran dan Warkshap & 24.277 & Watt \\
\hline CCTV, Fas ilit đ Karyawan dan Kantin & 5.204 & Watt \\
\hline
\end{tabular}

Berikut nilai power losses masing-masing panel pada fasa $\mathrm{R}$, fasa $\mathrm{S}$, fasa $\mathrm{T}$ dan netral serta nilai totalnya.

Tabel 13 Nilai total power losses akibat harmonik dan unbalance.

\begin{tabular}{|c|c|c|c|c|c|}
\hline Panel & Fasa $\mathrm{R}$ & Foss & Feset & Netral & Totel \\
\hline MDP & 22.958 & 35.493 & 34.545 & 13.284 & 107.291 \\
\hline Perakitan Teevisi & 18.401 & 26.535 & 29.945 & 10.372 & 85.204 \\
\hline Perakitan Hondphone & 208.63 & 22.233 & 93.347 & 164933 & 438.743 \\
\hline Logistik & 49.832 & 22.915 & 101.382 & 69.054 & 243.193 \\
\hline Perkgn toren den Workghop & 44.119 & 34.025 & 29.58 & 24.277 & 152.02 \\
\hline CCTV, Felites Karyewan den Kentin & 23.996 & 24.105 & 19.45 & 52204 & 72.72 \\
\hline Total & 367.905 & 185.357 & 308174 & 285.743 & 1149.17 \\
\hline
\end{tabular}

Tabel 14 Besar power losses penghantar tiap panel.

\begin{tabular}{|l|r|}
\hline \multicolumn{1}{|c|}{ Gedung } & Pawer Lasses (AP) \\
\hline MDP & 36.952 \\
\hline Perakitan Televisi & 21.862 \\
\hline Perakitan Handphane & 238.11 \\
\hline Lagistik & 125.94 \\
\hline Perkantaran dan Works hap & 57.503 \\
\hline CCTY, Fas ilita Karyawan dan Kantin & 19.461 \\
\hline Total & 499.828 \\
\hline
\end{tabular}

Setelah didapat nilai power losses dalam keadaan terdistorsi harmonik dan unbalance serta power losses dalam keadaan seimbang dan sinusoida, sekarang dapat diketahui nilai power losses murni akibat harmonik dan unbalance (tanpa power losses dari penghantar) dengan menghitung selisih dari kedua nilai tersebut.

Tabel 15 Besar power losses murni akibat harmonik dan unbalance.

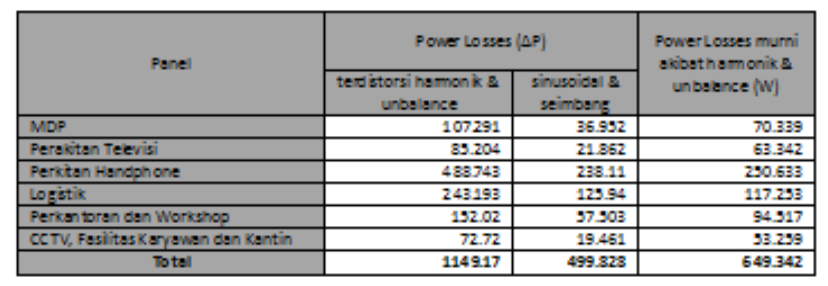

Perhitungan presentase power losses dibanding dengan total daya aktif yang terpakai. Total daya aktif yang dijadikan acuan adalah total daya aktif rata-rata pada panel MDP.

Tabel 16 Besar power losses harmonik dan unbalance panel MDP.

\begin{tabular}{|l|r|r|c|r|}
\hline Daya Nyata (W) & \multicolumn{1}{|c|}{ Fas a R } & \multicolumn{1}{c|}{ Fas aS } & Fas a T & \multicolumn{1}{c|}{ Tatal } \\
\hline Nilai Maksimum & 16364.41 & 27753.21 & 28848.92 & 72966.5 \\
\hline Nilai Minimum & 4279.08 & 9375.39 & 8228.49 & 21883 \\
\hline Fata-Fata & 9236.299 & 16405.52 & 18816.78 & 44458.6 \\
\hline
\end{tabular}

Tarif Dasar Listrik untuk Pelayanan Industri dengan batas daya diatas 200 kVA termasuk kedalam golongan tarif I-3/TM yaitu. Biaya perkWH untuk golongan ini dibagi menjadi dua, yaitu biaya WBP (Waktu Beban Puncak) dan biaya LWBP (Luar Waktu Beban Puncak). Perhitungan biaya yang harus dikeluarkan tiap hari, bulan dan tahun akibat rugi-rugi daya yang disebabkan oleh distorsi harmonik dan unbalance load (ketidakseimbangan beban). Keterangan : - biaya loses perbulan $=28$ hari, dengan pertimbangan satu bulan $=4$ minggu (28 hari).

Tabel 17 Besar biaya akibat power losses pertahun.

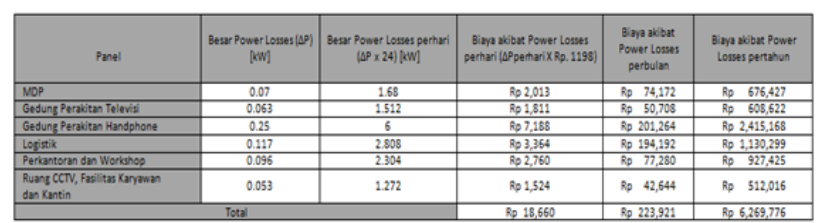

Dengan melihat hasil perhitungan diatas, kerugian akibat distorsi harmonik dan ketidakseimbangan beban cukup besar, setiap tahunnya harus mengeluarkan biaya sekitar $R p$. 6.269.776 untuk rugi-rugi daya akibat harmonisa dan unbalance. 
RESISTOR (elektRonika kEndali telekomunikaSI tenaga liSTrik kOmputeR) Vol. 1 No. 1 e-ISSN :

\section{KESIMPULAN}

Penyebab kurang baiknya kualitas daya listrik dikarenakan besarnya distorsi harmonik dan ketidakseimbangan beban pada tiap fasa, oleh karena itu harus segera melakukan pembenahan pada sektor distribusi beban pada tiap panel agar penggunaan beban seimbang pada tiap fasa sehingga rugi-rugi karena arus netral dapat diminimalisir. Disediakannya kapasitor bank untuk menaikkan nilai faktor daya dan untuk mengurangi THD (Total Harmonik Distortion) dapat dipasang filter harmonik yang dapat menyaring frekuensi selain frekuensi fundamental sehingga rugi-rugi akibat distorsi harmonik dapat ditekan.

\section{DAFTAR PUSTAKA}

[1] Budiyanto and Fadliondi, "The Improvement of Solar Cell Output Power Using Cooling and Reflection from Mirror," Int. J. Power Electron. Drive Syst., vol. 8, no. 3, pp. 13201326, 2017.

[2] Fadliondi, H. Isyanto, and P. G. Chamdareno, "The comparison of organic field effect transistor (OFET) structures," in 2017 2nd International Conference on Frontiers of Sensors Technologies (ICFST), 2017, pp. 6-9.

[3] F. Fadliondi and B. Budiyanto, "Transistor Efek Medan Berbasis Semikonduktor Organik Pentacene untuk Sensor Kelembaban," J. Nas. Tek. Elektro dan Teknol. Inf., vol. 6, no. 2, pp. 204-209, 2017.

[4] Fadliondi, M. K. Biddinika, and S.-I. Ohmi, "The humidity dependence of pentacene organic metal-oxide-semiconductor fieldeffect transistor," Telkomnika (Telecommunication Comput. Electron. Control., vol. 15, no. 2, pp. 578-583, 2017.

[5] E. B. Prasetya, "Pemantau Kebocoran Ac Menggunakan Sensor Y183 Dan Lm35dz Berbasis Mikrokontroler Arduino Melalui Webserver," Elektum J. Tek. Elektro, vol. 14, no. 2, pp. 49-56, 2017.

[6] Saeful Bahri and Chairul Anwar, "Perancangan dan Prototype Automatis Mesin Single Bore dengan Motor AC 1 Fasa Berbasis Pengontrolan Pneumatik dan PLC," Elektum J. Tek. Elektro, vol. 14, no. 2, pp. 13-20, 2017.

[7] H. Muchtar and D. Trihambodo, "Analisa Perbandingan Throughput pada Teknologi WiMAX," Elektum J. Tek. Elektro, vol. 14, no. 2, pp. 1-12, 2017.
[8] H. Isyanto and J. Waloya, "Analisa Kemampuan Daya Pancar pada Gelombang Fm dengan Antena Dipole," Elektum J. Tek. Elektro, vol. 14, no. 2, pp. 21-24, 2017.

[9] M. A. Soomro, A. A. Sahito, I. A. Halepoto, and K. Kazi, "Single Tuned Harmonic Shunt Passive Filter Design for Suppressing Dominant Odd Order Harmonics in order to Improve Energy Efficiency," Indian J. Sci. Technol., vol. 9, no. December, pp. 1-6, 2016.

[10] S. Bhattacharyya, A. Choudhury, and P. H. R. Jariwala, "Case Study On Power Factor Improvement," Int. J. Eng. Sci. Technol., vol. 3, no. 12, pp. 8372-8378, 2011.

[11] P. Manikandan, A. Krishnaveni, D. E. Selvaraj, M. Muthukumaran, and J. Ganesan, "a Review on Importance of Universal," J. Club Electr. Eng., vol. 2, no. 1, pp. 72-78, 2015.

[12] M. Ravindran and V. Kirubakaran, "Electrical Energy Conservation in Automatic Power Factor Correction by Embedded System," Energy and Power, vol. 2, no. 4, pp. 51-54, 2012.

[13] G. Deb, P. S. Saha, and P. Das, "A Method of Finding Capacitor Value for Power Factor Improvement," Int. J. Electr. Eng., vol. 4, no. 8, pp. 913-922, 2011. 
RESISTOR (elektRonika kEndali telekomunikaSI tenaga liSTrik kOmputeR) Vol. 1 No. 1 e-ISSN : 